\title{
Taking the leap and sustaining the journey: Diversification on the Irish family farm
}

\author{
Aisling Moroney, ${ }^{\mathrm{a}} *$ Seamus O'Reilly, ${ }^{\mathrm{b}}$ and Mary O'Shaughnessy ${ }^{\mathrm{c}}$ \\ Department of Food Business and Development, University College Cork
}

Submitted November 2, 2015 / Revised January 29 and March 29, 2016 / Accepted March 29, 2016 /

Published online August 31, 2016

Citation: Moroney, A., O'Reilly, S., \& O’Shaughnessy, M. (2016). Taking the leap and sustaining the

journey: Diversification on the Irish family farm. Journal of Agriculture, Food Systems, and Community

Development, 6(4), 103-123. http://dx.doi.org/10.5304/jafscd.2016.064.004

Copyright (C) 2016 by New Leaf Associates, Inc.

\begin{abstract}
A range of push and pull factors encourage Irish farmers to diversify their operations, but they remain largely reluctant entrepreneurs, wedded to productivist models of agriculture. This paper is based on a study which involved intensive interviews conducted throughout Ireland in 2013 with a sample of 15 farm households who are "bucking the trend" and selling farm produce into short food supply chains. Using the literature on farm entrepreneurialism as an organizing framework, this paper explores the journey taken by these farm households and identifies the motivations and abilities that initiate and sustain this behavior. The results demonstrate the dynamic and complex nature of family farm entrepreneurialism. Of

a * Corresponding author: Dr. Aisling Moroney, Department of Food Business and Development, University College Cork; Cork, Ireland; +00353 86 1724162; a.moroney@ucc.ie

b Department of Food Business and Development, University College Cork; $\underline{\text { S.OReilly@,ucc.ie }}$

${ }^{\mathrm{c}}$ Department of Food Business and Development, University College Cork; Mary.oshaughnessy@ucc.ie
\end{abstract}

particular note is the importance of more ideological and socio-cultural motivations. This highlights the need for farm diversification supports to be themselves multifaceted as well as tailored to the circumstances of individual farm households. The paper emphasizes the inherent value of the more small-scale farmer entrepreneurs who may never "scale up," but who contribute to overall rural sustainability and economic life and who are meeting their own multiple goals.

\section{Keywords}

Farm Diversification; Entrepreneurialism; Family Farm; Short Food Supply Chains; Alternative Farm Enterprises

\footnotetext{
Authors Note

This research paper arose out of a research project commissioned by the Irish National Rural Network (NRN) to investigate the experience of Irish farm households selling into short food supply chains. The authors would like to acknowledge the financial and other supports provided by the NRN. The report is available at http://www.nrn.ie/wpcontent/uploads/2013/06/Final-Case-Study-Short-FoodSupply-Chains-Jun-2013.pdf
} 


\section{Introduction}

A range of converging developments within European agriculture and rural development-ongoing reform of the Common Agricultural Policy (CAP) and increased market liberalization; the focus on a more multifunctional agriculture; the opportunities presented by the "quality turn" in the food industry - mean that farmers are increasingly encouraged to be more entrepreneurial in their approach to farm and resource management. Diversification into activities outside mainstream or conventional agriculture has attracted significant attention at both policy level (Clark, 2009) and within the literature (Alsos, Ljunggren, \& Pettersen, 2003; Anthopoulou, 2010; Grande, 2011; Hansson, Ferguson, Olofsson, \& Rantamäki-Lahtinen, 2013; Northcote \& Alonso, 2011; Vik \& McElwee, 2011). This study is concerned with diversification by Irish farm families into one particular type of food-related activity: sales of farm produce into short food supply chains. These are the range of food production-distribution-consumption configurations (such as sales at farmers markets and farm shops, and sales to restaurants and artisanal outlets) that facilitate either a short distance or a small number of intermediaries between producers and consumers (Renting, Marsden, \& Banks, 2003) and that are particularly associated with more artisanal and specialized products and with less intensive production methods. For reasons that will be explored later, Irish farmers have been largely reluctant entrepreneurs to date and have been particularly unlikely to pursue added-value food production. This study asks what distinguishes those farm families who have taken the unusual step of pursuing added-value food production and sales into short food supply chains? It investigates factors such as entrepreneurial orientation and personality, family factors, motivation, and entrepreneurial triggers, and explores what abilities and characteristics sustain the farm families on their journey within this niche "corner" of the Irish agriculture and food industry. The paper opens with a discussion of the literature on farm family entrepreneurialism and

${ }^{1}$ The Rural Environmental Protection Scheme is designed to reward farmers for farming in an environmentally friendly diversification, with a particular emphasis on motivations and triggers and on the complexities of farm business decision-making. The discussion then moves to the specificities of the Irish situation, which provide the context and justification for the study. This is followed by a more detailed discussion of the study parameters, the terms used, and the units of analysis. Next, we describe the methodology used and explain its methodological underpinnings. The results and analysis section provides a profile of the participating farm businesses and a description of the diversification "decision" and of the ongoing entrepreneurial journey. A more interpretative section that also draws on the relevant literature follows the findings. The paper concludes with some suggestions for encouraging further farm diversification and for future research.

\section{Farm Family Entrepreneurialism and Diversification}

A range of definitions of farm diversification is offered in the literature (Ilbery, 1992; Ilbery \& Bowler, 1998; McNally, 2001; Vik \& McElwee, 2011). Ilbery and Bowler (1998) offer one of the most expansive: "the generation by farm households of income from on-farm and/or off-farm sources in addition to income obtained from primary agriculture" (p. 75). Within this definition, off-farm employment, investments, income from EU or government subsidies, or from participation in schemes such as the Rural Environmental Protection Scheme ${ }^{1}$ all could be considered a form of diversification. We are in agreement with Vik \& McElwee (2011) that such a definition more properly describes a kind of pluriactivity. For this study, we view diversification more narrowly as the "development of non-traditional (alternative) enterprises [our emphasis] on the farm" (Ilbery, 1992, p. 102). The farm households in this study are still primarily engaged in food production - the most traditional of farm activities - and some definitions of farm diversification would specifically exclude them (McNally, 2001; Woods, 2005). In addition to food production, however, they are pursuing

manner and began in Ireland in 1994. 
alternative sales, distribution, and in many cases, production methods, and it is this aspect of their operations that is entrepreneurial in nature.

As Vik and McElwee (2011) note, the relationship between the farmer and the farm business is a complex issue, suggesting that the methods used to analyse business entrepreneurs in other sectors may not be easily transferred to an analysis of farms and farmers. A range of studies suggest that a complex web of motivations and perspectives, only some of which are strictly concerned with economic logic, inform decision-making in general at the farm level. These include the desire for autonomy and for quality of life for self and family, the aspirations for social standing and belonging among fellow farmers and the rural community, the wish to preserve family heritage; and the desire to be a "good" farmer and meet customer expectations (Gasson \& Errington, 1993; Hansson et al., 2013; Hildenbrand \& Hennon, 2008; Seuneke, Lans, \& Wiskerke, 2013). Hansson et al. (2013) draw important attention to the two interconnected and indivisible dimensions of the farm (the farm and the farmer's family living on the farm) and suggest that making a profit is but one element of its utility function. As Gasson and Errington (1993) have noted, the farm business is typically run not just with the aim of securing and operating profit in the current year, but also of securing a livelihood for the next generation of the family. This suggests that the entrepreneurial journey of the kind of farm families that are the subject of this study may be nuanced and long-range in nature, encompassing the skills, perspectives, and ambitions of a number of members of the family. The complexity of farmers and farm household motivations is perhaps amplified further in cases of farm diversification; Vik and McElwee (2011) found that social motivations are as important as economic motivations, and further, there are substantial differences in which motivations underpin different types of diversification. Similarly, Hansson et al. (2013) found that diversification outside conventional agriculture among the Swedish farm households in their study was viewed as both a businessdevelopment strategy to reduce risk and use idle resources, and a development strategy for social and lifestyle reasons. Based on their research with olive growing farmers in Western Australia, Northcote and Alsonso (2011) concluded that diversification is best seen as a continuum of adjustment strategies, which is guided by a combination of economic need, risk assessment (based largely on resource access), market potential, and lifestyle factors.

A common framework within which the entrepreneurial impulse is analyzed in the literature is in terms of "push" and "pull" factors, where diversification outside conventional agriculture is seen as "opportunity driven" (pull factor) or "necessity driven" (push factor) (Hansson et al., 2013). The range of pull factors identified in studies of food-based farm diversification include improved financial returns and the opportunity to circumvent the rigors and inflexibilities that can characterize the conventional food supply chain (Guthrie, Guthrie, Lawson \& Cameron, 2006; Smithers, Lamarche \& Joseph, 2008). Studies of farmer participation in farmers markets have highlighted the contribution participation in direct sales makes to the entrepreneurial development of participants (Feagan, Morris, \& Krug, 2004; Feenstra, Lewis, Hinrichs, Gillespie, \& Hilchey, 2003). Face-to-face interactions and personal relations have been found to enable, perhaps even force, farmers markets stallholders to develop what Hinrichs, Gillespie, and Feenstra (2004) describe as a greater reflexivity about the form and content of economic activity. In the case of push factors, Hansson et al. (2013) suggest that the farmer has to diversify in order to become or remain selfemployed, secure family income, or decrease risks caused by changes in the market situation. The latter is closely linked to the notion of the "survival entrepreneur" who creates an enterprise due to a dearth of other income options and a desire to sustain him- or herself and his or her family (Dabson, 2008) rather than from any great desire to be an entrepreneur. Power imbalances within the conventional food supply chain and the everdecreasing share of the food-euro received by the primary producer have been identified as strong push factors to explore food-led diversification and value-added projects (Renting et al., 2003; Slee \& Kirwan, 2007).

Further insight is provided by the literature on 
which factors trigger the entrepreneurial response. Hennon (2012) argues that there are two types of trigger, the first of which is "intention" and which he suggests originates from a person's characteristics: optimism, internal locus of control, propensity for risk-taking, craving for achievement, wanting autonomy, or wanting to be in control. Clearly, the farmer in this case is more pulled by internal characteristics and personality factors than pushed by events into the decision to embark on a diversified farm enterprise. The literature suggests that the opportunity to operate autonomously, or to act of one's own volition, is more typically found within diversified farm businesses than in conventional productivist agricultural operations (Hinrichs et al., 2004; Renting et al., 2003; Slee \& Kirwan, 2007). The push factor is in some cases stronger in the second trigger described by Hennon (2012) as "displacement" or a disruption of a person's life. He argues that the change in one's behavior leading to an entrepreneurial action can proceed from either positive factors, such as a potential funding source or a family atmosphere promoting entrepreneurial adventures, or, alternatively, from negative factors such as being made redundant or marital disruption or unstable income. He further subdivides "displacements" into those internal to the person, such as personal dissatisfaction, the belief that one is not advancing professionally or careerwise, or age-related feelings that it is "now or never" (as described by Degeorge \& Fayolle, 2011), and those external to the person, such as their social and employment life. Rarely mentioned in the literature but of significant interest to us in this study is the extent to which farmers can "fall into" diversification and become accidental (though not necessarily reluctant) entrepreneurs through a series of chance encounters or incremental changes. In this, we are in agreement with Vik and McElwee (2011), who suggest that processes of diversification may be more incremental and accidental than strategically planned, that becoming entrepreneurial may be less an event than a creeping process.

A further strand in the literature on farm entrepreneurship focuses on skills and attributes. McElwee and Robson (2004) identify six key sets of skills (business and management skills; cooperation and networking; information technology; marketing and selling; entrepreneurial qualities and values; and technical and professional), while Hennon (2012) distinguishes between what he refers to as higher-level, more entrepreneurial skills, which have to do with initiating and advancing an enterprise, recognizing and realizing business opportunities, strategizing, networking, etc., and lower-level, managerial skills related to production, administration, and marketing. We can speculate that the particular type of entrepreneurial activity undertaken by the farm households in this study - end-consumer focused and sales-leddemands specific skills and capacities (McElwee \& Bosworth, 2010). The kind of personality factors associated with entrepreneurial activity identified in the literature include proactiveness, autonomy, risk-taking, self-belief, and optimism (Covin \& Wales, 2011; Lumpkin \& Dess, 1996; McElwee, 2008). Hennon (2012) uses the term "entrepreneurial vivacity" to encompass many of these traits and also draws attention to the importance of what he describes as "entrepreneurial astuteness." The presence of these kinds of skills and attributes may be fundamental to the decision to diversify from mainstream agricultural activity. We can also speculate that they may be key to the success and durability of the enterprise and that the opportunity to utilize them may be central to the job (and perhaps life) satisfaction of the participants in the research. Other studies (McElwee \& Bosworth, 2010; Meredith, Heanue, \& McCarthy, 2012) have noted the strong relationship between high education levels and/or working experience outside agriculture and a propensity for farm innovation and diversification. Woven throughout the above, if not always explicitly stated, is the external economic, social, and cultural milieu that incentivizes—or otherwise — the farmer to diversify. Factors such as market conditions, the policy environment, availability of financing and grant funding and/or soft supports, and attitudes of other farmers and rural actors all play their part in framing the entrepreneurial journey and have been highlighted in a range of studies (Clark, 2009; Cooke, 1998). 


\section{The Irish Context and the Basis for the Study}

In the Irish context, the wider benefits of this type of farm-based entrepreneurial activity have been increasingly recognized by statutory and local and rural development actors. Support for this type of diversification activity is very much in tune with the European Union post-productivist rural development agenda and the shift toward a more placebased and multifunctional approach to agriculture, which Ireland has embraced with some enthusiasm (Brown, 2010). There is also a growing emphasis on the contribution of local food cultures and local food networks to the tourism mix and to the successful branding of Ireland as the Food Island (Bord Bia, 2007; Grant Thornton, 2012). Pressure to explore alternative farm enterprises also comes from what can be described as a bifurcated system with a "contracting minority of commercial farms... [and] an expanding majority of farms increasingly dependent for survival on policy interventions and/or off-farm income" (Crowley \& Meredith, 2015, pp. 188-189). In 2010, just over $25 \%$ of all Irish farms were classified as economically viable, a further $38 \%$ were deemed sustainable, and the remaining 36\% were classified as economically vulnerable (Crowley \& Meredith, 2015). The sharp decline in off-farm employment of farm households in recent years, from $59 \%$ in 2006 to 50\% in 2012 (Teagasc, 2012) is also significant: off-farm employment has long been the most significant source of alternative or additional income on Irish farms.

Notwithstanding these trends, recent research documents the difficulties experienced in encouraging contemporary farm diversification and, more specifically, the pursuit of added value or speciality food production among contemporary Irish farmers (Macken-Walsh, 2009; Meredith, 2011; Meredith et al., 2012; Tovey, 2009). The foundation of the Irish agri-food sector is the extensive, grass-based system of livestock production that allows for the relatively low-cost production of natural, high-quality commodities. Ireland is largely self-sufficient across a range of key agricultural products and is overwhelmingly so in relation to beef and dairy, which together account for $69 \%$ of the goods output of Irish agriculture (Department of Agriculture, Food and the Marine, 2015). This productivist agenda has resulted in $80 \%$ of all Irish farms being classified as specialist farms, with more than $50 \%$ of all Irish farmers reported to engage solely in beef cattle production (Crowley \& Meredith, 2015). It has also been noted that the farm sector, which is $97 \%$ family-run, is "increasingly comprised of [sic] low-income and economically unviable farms" (Crowley \& Meredith, 2015, p. 179).

The small size of the domestic market and limited food culture (Fonte, 2008; Tovey, 2009), combined with high production levels in key commodities, has meant that Ireland has long pursued an export-oriented, rather than domestically oriented or farm-level value-added, model of agriculture. The great majority of the approximately 139,860 Irish farm households could be classified as Type 1, "the farmer as farmer" in the classification arrived at by McElwee (2008). Most have not engaged with the growing local foods dynamic and remain price-takers in commodity markets rather than price-setters in short food supply chains (Macken-Walsh, 2009). Recent figures suggest that just $4.1 \%$ of Irish farmers have diversified, compared with $51 \%$ of English farmers (Meredith, 2011) and up to 59\% of Norwegian farmers (Haugen \& Vik, 2008), and that only $0.4 \%$ Irish farmers have gone into adding value to food. In a 2012 study, Meredith, Heanue, and McCarthy found that in a sample of 472 farmers nationwide, just $\%$ expressed a preference for setting up a diversified, farm-based business as a farm development strategy. Macken-Walsh's important study of barriers to participation of farmers in local food movements (2009) suggests that Irish farmers' occupational preferences are strongly rooted in forms of cultural and social capital that can be estranged from the consumer-driven economic activities promoted by rural development actors. The perception of food markets and production of artisan foods as being "not for farmers" and "not suitable for farmers" was prevalent in the data collected from farmers in Macken-Walsh's research. Heanue and Macken-Walsh (2010) also suggest that a large proportion of farm-holders are unlikely to have the necessary expertise in processing, branding, marketing, advertising, and 
distribution activities to participate fully or independently in more entrepreneurial activities. A number of studies (Moore, 2003; Tovey, 2006) have revealed that local food initiatives have been strongly influenced—and often led-by incomers to Ireland, by people not from traditional farming backgrounds, and by those who see themselves as part of a consumer movement as much as a rural producer movement.

There has clearly been much recent research interest in the lack of diversification into addedvalue food enterprises among Irish farmers and the complex mix of economic, social and cultural factors that may lie behind it. Drawing on empirical data from interviews with a sample of 15 Irish farm families who are involved to varying degrees in short food supply chain activity, this paper acts as a counterpoint to these studies. The central research question is, what distinguishes those farm families who have taken the unusual step of pursuing added-value food production and sales into short food supply chains? To return to McElwee's earlier classification (2008), it asks why these particular farmers are (or have become) "farmers as entrepreneurs," when the vast majority of their peers could not be so described. As noted earlier, it investigates factors such as entrepreneurial orientation and personality, family factors, motivation, and entrepreneurial triggers. This study also explores what abilities and characteristics sustain the farm families on their journey within this growing, but still niche, "corner" of the Irish agriculture and food industry. The literature on entrepreneur motivations has tended to be concerned with startup rather than sustaining business ownership; as Jayawarna, Rouse and Kitching (2013) have noted, studies often implicitly assume that start-up motivations influence all subsequent behavior, rather than that they change over the life course of the business with entrepreneur experience The term "entrepreneurial journey" is used to capture the unfolding nature of the entrepreneurial life (Jayawarna, Rouse, \& Macpherson, 2007) and draws from the life course perspective, in which entrepreneurial intention, action, and performance

2 The main focus of the literature has tended to be on are embedded in and shaped by the social, economic, and cultural environments as well as by factors such as timing, family background and relationships, social ties, and human agency and control (Hutchison, 2011; Jayawarna et al., 2013).

The unit of analysis in this study is the farm family or household selling into short food supply chains, rather than the individual farmer. This follows the tradition in sociology of studying farms as family units (Gasson, Crow, Errington, Hutson, Marsden \& Winter, 1988; Gasson \& Errington, 1993; Whatmore, 1991) and more recent studies that have highlighted the particular importance of wider family involvement in diversified farm operations (Alsos et al., 2003; Hansson et al., 2013). Family farming has been described as "an institution that is particularly enduring in the Irish countryside" (Macken-Walsh, Byrne, Curran, \& Roche, 2014, p. 28), with farming seen as predominately a family business. While this study does not necessarily examine in depth the complex dynamics that may exist within farm households (such as succession issues, gender relations, division of labor, etc.), to restrict the study to the individual or "main" farmer would ignore the fact that the family farm in Ireland is typically "not only an economic business, but a site of shared social relationships and practices and a culturallyesteemed knowledge source" (Macken-Walsh et al., 2014, p. 28). More general research on family businesses - of which the farms included in this study can be considered examples-is relatively young but has grown substantially in recent years (Wright \& Kellermanns, 2011). However, to date little attention has been paid to the particular case of the farm family business or to entrepreneurialism in either the family business setting generally (Hofmann, 2009), ${ }^{2}$ or the farm family business setting specifically (McElwee \& Bosworth, 2010). Consequently, the research outlined is of a qualitative, exploratory nature, and in examining the complex web of economic, social, and personal factors in the entrepreneurial journey of a sample of farm households, it contributes to the family business literature as well as to the growing farm entrepreneurship literature (Phelan \& Sharpley, 2011).

succession, performance and governance (Hofmann, 2009). 


\section{Applied Research Methods}

This study undertook to examine the motivations, skills, and experiences of a sample of Irish farm households who have engaged to varying degrees in a particular type of farm diversification. Some recent studies in this area (Anthopoulou, 2010; Hansson et al., 2013; Vik \& McElwee, 2011) have tended to use larger samples and focus on one dimension or grouping within this sphere, such as gender or family involvement. This study sought to take a smaller sample and explore in depth the complex web of motives and experiences in an approach more akin to studies undertaken by Grande (2011) and Northcote and Alonso (2011). We adopted a qualitative approach as we sought to understand the world from the perspective of the farm households who have engaged with short food supply chains. As such, we take a phenomenological perspective to reveal the persistent thoughts (including motivations), feelings, and abilities that sustain behaviors associated with being a short food supply chain farmer. The journey travelled by these farmers was of particular interest, as this provided a suitable lens through which motivations, decisions, experiences, and felt outcomes became evident. In tracing this journey, the researchers sought to evoke lived memory in an approach similar to that suggested by Smith and McElwee (2013). The emphasis of this study is on a more micro-level perspective, which concentrates on typical experiences and situations from which larger generalizations can then be inferred; that is, on analytical generalization rather than statistical generalization. While this approach has much to offer research in the farmer entrepreneurship field (and indeed in the wider field of entrepreneurship) as evident from Hildenbrand and Hennon (2008), Couzy and Dockes (2008) and McElwee (2008), it

Table 1. Profiles of Farm Businesses in the Study

\begin{tabular}{|c|c|c|c|c|c|c|}
\hline $\begin{array}{l}\text { Participant } \\
\text { No. } \\
\end{array}$ & Product Type(s) & $\begin{array}{l}\text { Main Outlets for } \\
\text { Produce }^{*}\end{array}$ & $\begin{array}{l}\text { Location } \\
\text { in Ireland }\end{array}$ & $\begin{array}{c}\text { Size of Land } \\
\text { Holding** }\end{array}$ & $\begin{array}{c}\text { Alongside } \\
\text { Conventional } \\
\text { Operation (Yes/No) } \\
\end{array}$ & $\begin{array}{c}\text { Number } \\
\text { Employed } \\
\text { (Full-time) }\end{array}$ \\
\hline F1 & Venison & FMs, SRs, Rs, online & Northwest & Large & No & 1 \\
\hline F2 & Flax oil & SRs, FMs, Ss & Midlands & Medium & No & 2 \\
\hline F3 & $\begin{array}{l}\text { Organic meats, } \\
\text { vegetables }\end{array}$ & FMs, FG, CV, Rs & Midlands & Large & No & 2 \\
\hline F4 & Poultry, eggs & FMs, Rs, CS & South & Medium & Yes & 1 \\
\hline F5 & Luxury ice-cream & Rs, SRs & South-east & Large & Yes & 2 \\
\hline F6 & Lamb & FG, D & Southwest & Medium & Yes & 1 \\
\hline F7 & $\begin{array}{l}\text { Organic eggs, jams, } \\
\text { vegetables }\end{array}$ & FMs, FG, Rs, CSA & Co Dublin & Medium & No & 1 \\
\hline F8 & Lamb, beef & FS, FMs, SR, Rs & West & Medium & No & 10 \\
\hline F9 & Specialist beef & Rs, online & South & Large & No & 1 \\
\hline F10 & $\begin{array}{l}\text { Goats milk and } \\
\text { products }\end{array}$ & FMs, Ss, SR & Northeast & Medium & No & 1 \\
\hline F11 & Baked goods & Ss, BS, FMs & East & Large & Yes & 18 \\
\hline F12 & Organic vegetables & SRs, Rs, FMs & West & Small & No & 1 \\
\hline F13 & $\begin{array}{l}\text { Organic vegetables, } \\
\text { eggs, jams }\end{array}$ & FMs, FG & South & Small & No & 2 \\
\hline F14 & Organic beef & FMs, SR & Northeast & Small & No & 1 \\
\hline F15 & Vegetables & Ss, Rs, FMs, FG & Midlands & Medium & Yes & 3 \\
\hline
\end{tabular}

* Acronyms:

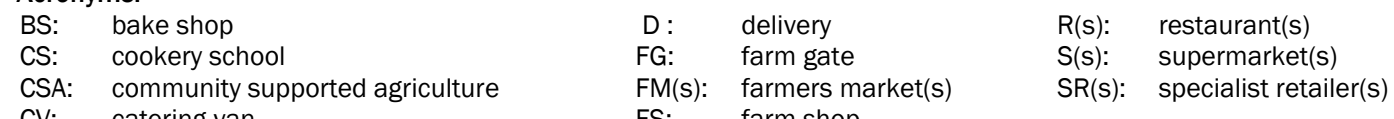

CV: catering van $\quad F S$ farm shop

$* *$ Large $=>50$ hectares; Medium $=20-50$ ha; Small $=<20$ ha

Source: The classification used is specific to the Irish situation and is that used in the most recent Census of Agriculture (2010) carried out by the Central Statistics Office. 
has been somewhat neglected. Indeed McElwee (2008) champions this cause and calls for further phenomenological inquiry. This study also necessarily goes beyond the perspective of pure economic rationality to focus on developing a more holistic understanding of individual and social perspectives and behavior.

Participants for the study were chosen using purposive sampling, using the expertise and industry knowledge of the researchers, who are academics in this field, and of staff from a range of support and development agencies. The latter include the National Rural Network and a number of local development groups with particular experience of working with actors in short food supply chains. Drawing on Yin's (2003) suggestions about contrasting cases, the study sought to be somewhat representative of the totality of experience (knowledge of which was based on the researchers' and key informants' experiences in the sector) but to also include a range of backgrounds, size and type of farms, locations, and other characteristics. The final sample of 15 also included a number of mature, successful producers (i.e., those with a length and depth of experience in added-value food production and selling into short food supply chains), a number operating at a relatively simple or small-scale level, and a number of farm households who are simultaneously continuing with commodity production and also participating in short food supply chains. A reasonable geographic spread was also achieved, although a more important spatial consideration in this area of research is proximity (or otherwise) to the marketplace and high-quality intermediaries. The sample of 15 provides a substantial range and depth of experience within this (currently very small) subset of Irish farm households.

Table 1 provides a profile of the 15 participating farm businesses, outlining the main product types and outlets; the location, size, and quality of land holding; and the numbers employed. It also indicates whether the farming businesses continue to operate a conventional farming operation alongside their more value-added activities. Figure 1 maps the participating farm businesses.

Participants were sent a copy of the interview guide by email prior to interviews and all of the 
interviews lasted between 45 and 75 minutes. The majority of the interviews took place via telephone or Skype, with a small number (three) conducted face to face. As noted previously, the unit of analysis in this study is the "farm household" rather than "the farmer," and so interviewees could be any representative of that household who was significantly involved in that aspect of the farm business. Where the term "farmer" is used in this study, it is taken to encompass all the members of the farm household involved in the diversification activity. The semistructured interview guide initially covered areas such as the background, education and experience of the farmer/farm household, and a description of the farm holding and of the type and range of short food supply chain activity. It then asked more probing questions regarding the key areas of interest in the study, including the motivation to engage in this type of activity and key push and/or pull factors; the goals and values of the members of the farm household; the skills and experience of individual household members; and the level of family involvement. Measuring the weight of the various factors in the decisionmaking process of such farm households is a complex process, and participants were simply asked, without detailed prompting, to outline their own recollection and ongoing understanding of their motivations, goals, values, skills, and other characteristics. From this process, a number of common themes emerged that are outlined in the results. As an exploratory study, the discussion also inevitably ranged over a wider range of topics relating to agriculture and the food industry than might have been originally envisaged. This is a normal, indeed desirable, feature of more exploratory research, which adds to the richness of the data set and which, as we shall see, sheds particular light on the complex motivations and abilities of farm households engaging in this kind of activity.

\section{Results and Analysis}

\section{Profile of Individual Farm Households}

Table 1 above provides a summary profile of the 15 farm businesses who participated in this study,

\footnotetext{
${ }^{3}$ In most cases, this is a husband-and-wife team, but in a small
}

but a number of other features associated with the farm bousebold also emerged. In the first instance, the decision to adopt the "farm household" rather "the farmer" as the unit of study for this research has been validated by the profile of the participants that has emerged. All but one of the participating households have least two members involved in short food supply chain activity, although the level of involvement varies. In six cases, at least two members of the farm household are employed fulltime in the enterprise. ${ }^{3}$ In the remaining households, the involvement of other family members varies from skills-based support around particular aspects of the business (for example, web design or marketing) to more general supplementary labor, such as helping run the production side of the operation or filling in at farmers markets or doing deliveries. This resonates strongly with other studies of farm diversification, which have highlighted the importance of family involvement in diversification activities (Alsos et al., 2003; Hansson et al., 2013).

Eleven of the participating farm households had at least one member who had been involved in farming throughout their lives, although in a small number of cases this may have been only on a parttime or casual basis until the death or incapacity of parents. Four of the participating households have come into agriculture and food production in the last decade through either inheritance or their own purchase of land. Two of the interviewees describe themselves as having "just hands-on" experience but no formal qualifications. Among the remaining 13 households, there are 10 members who could be described as having particularly relevant qualifications (that is, in agriculture, horticulture, or speciality food production). There are a wide variety of other educational backgrounds and qualifications evident among the farm households in this study, including three nurses, an engineer, two scientists, an accountant, and a graphic designer. Within the households, there are seven where one member has not worked outside of farming or food production at any stage. However, in only two of these households was there not another

number of cases, it is siblings or parents and children. 
family member with a previous or current "outside" job or work experience. Therefore, in 13 out of 15 cases - and in line with the qualifications described above - at least one member of the farm household has had significant work and life experience outside of agriculture and food. Again, this is congruent with other studies in this field (McElwee \& Bosworth, 2010; Meert, Van Huylenbroeck,
Vernimmen, Bourgeois \& van Hecke, 2005) that have highlighted the role of educational attainment and working experience outside agriculture in farm-based innovation.

The Diversification Decision: A Complex Mix of Motivating Factors

Figure 2 summarizes the motivations of the farm

Figure 2. Summary of Motivations to Diversify and Sell into Short Food Supply Chains

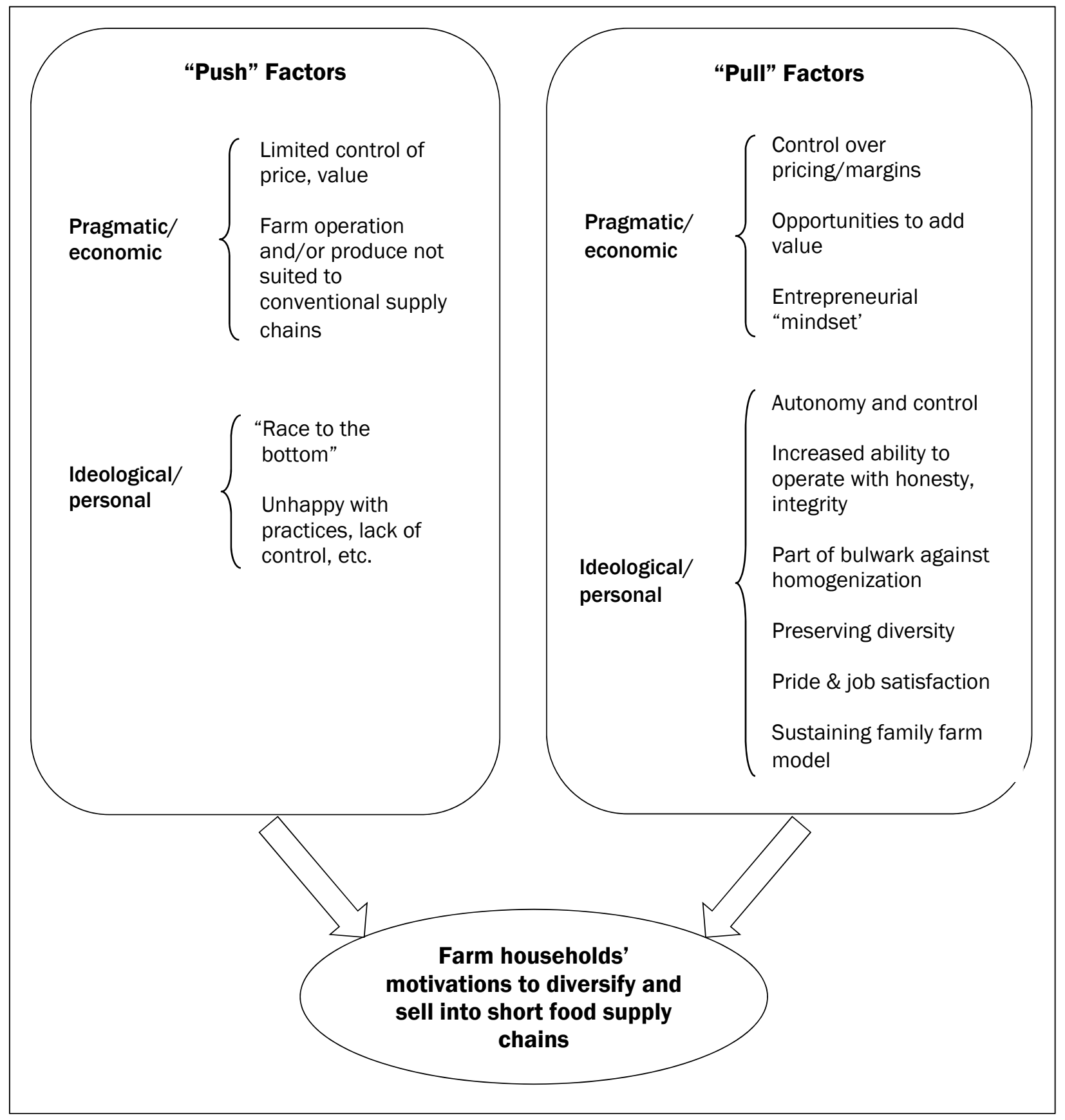


households in this study for diversifying and selling into short food supply chains. Given the heterogeneous nature of the households that participated in this study, it is unsurprising that a wide range of motivations underpins the decision to add value to produce and to engage more directly with consumers. Of particular interest is the finding that individual farm households are themselves typically motivated by a complex mix of pragmatic, financial, ideological, and personal factors in their entrepreneurial journey, which are summarized in the table below. Also notable is the somewhat stronger emphasis on pull factors among the participants in this study.

A small number of participants (F11, F9) would describe themselves as having "fallen into" direct sales. F11 described how she initially simply took over from her mother-in-law in supplying brown bread and scones to local shops when the latter took ill. Along with her husband she now employs 18 people and supplies baked goods to retailers and operates a bakery shop. These participants remain in this "space" for some or all of the same reasons that motivated their peers to diversify. For another further small number of participants in this study (F12, F13), a smallholding was purchased with the deliberate intent to operate within short food supply chains, producing organic, artisanal goods. Strictly speaking, these households did not diversify so much as choose their business model from the beginning, with the "pull" factors outlined in Figure 2 predominating. One couple (F13) bought a smallholding of eleven acres over a decade ago with a view to eventually operating a mixed organic operation from which products would be sold directly to the public via the farm gate and farmers markets. They continued to work off-farm and take relevant courses for a time while getting the operation up and running, but are now both employed full-time growing, processing, and selling. Although their trajectory may differ from most of the other participants, their case is typical of the strong intertwining of ideological, personal, financial, and family motivations found in this type of diversification activity.

However, in the majority of cases the pursuit of this type of diversification was a more deliberate and conscious decision. The limitations of conventional agricultural systems and the requirements to substantially increase production envisaged within national agri-food policy were strong push factors for the households in this study. F4 was originally a dairy farmer who found himself unable to expand his herd due to the fragmentation of his farm and the investments required under the European Union's Nitrates Directive. Instead, in addition to tillage, he began selling poultry and eggs directly to consumers and selected intermediaries. This decision was a significant turning point, and the autonomy gained from the diversification decision empowers this farmer to live by principles of fundamental importance to him in a sustained manner. For example, when speaking about business decisions taken with regard to the selection of intermediaries, he declared, "honesty and integrity are the big thing for me. I like to have total control and I'm very slow to diversify out where I don't have that." Similarly, albeit with a stronger commercial focus, is F7, an organic vegetable grower who used to operate as a market gardener at an intensive (high input) level. This led to what he describes as a "race to the bottom," where "the guy with two hundred acres was taken over by the guy with five hundred acres and in turn by the guy with thousand acres." For him, the best option was a return to a mixed, small-scale operation where he could capitalize on increasing opportunities to sell directly to the public: "The market turned the corner....There are opportunities there to compete on quality and through direct sales, with no middleman."

Autonomy and control over pricing emerged as major themes in the interviews. Meat producers, in particular, expressed a strong desire to improve the margins on each animal over and above the prices typically offered by conventional meat processors. One farmer explained his motivation to start selling directly and ultimately to open a farm shop:

I believed that the Irish family farm could make a living by adding value, by becoming price setters rather than takers....I wanted to take some control back. I saw my father struggling his whole life and my brother disillusioned at an early stage and I knew 
that it could be different. (F8)

An organic beef farmer expressed similar views:

The organic growing probably came first but the main motivation was to have some control over pricing and income, to not be subject to the whims of prices being offered by factories and to control what's happening with what we produce. (F3)

These findings highlight not only the importance of autonomy but also how this is linked to an ideology that values diversity and, ultimately, the presence of large numbers of small-scale producers. F15 also reflects on the "race to the bottom" that squeezes out smaller producers:

It's important that we keep going and people need to work together more to avoid monopolies. The smaller ones are getting squeezed out; we'll be importing potatoes when the bigger guys hit the wall! (F15)

Such an ideological commitment to exploring alternatives to the conventional food system underpins much of the decision-making of the farm households. For a substantial number of households in this study, the method of selling appears inextricably linked with-and to some extent, determined by - the distinct nature of the products they have to offer and their overall attitude to the food system. Many of these food entrepreneurs see themselves as a bulwark against growing homogeneity and centralization within the wider food system, both in terms of what they produce and how they sell:

I would always say that people have gotten away from where food comes from and I like to be part of a different, I suppose more sane way of doing things. (F14)

Linked to this is the increased sense of pride and job satisfaction often associated with more direct sales. One farmer noted:

In 20 years of dairying, no one ever said "that was a nice glass of milk," but now I have people coming up to me saying "they were lovely eggs" or "I haven't had a chicken like that since I was a child." (F4)

The fit between an ideology related to production methods, scale, etc., and a shorter, more direct supply chain is evident. For those producing artisanal, organic, premium, or speciality products at a relatively small scale, short food supply chains are the natural and more financially rewarding route to their necessarily limited customer base. The journey of one organic beef producer is typical:

I was always interested in biodiversity and from when I went organic, I started selling directly to local families....It's the breeds [Aberdeen Angus and Shorthorn] and the organic status that determines the sales premium and the choice of outlets. (F14)

A level of attachment to the business model is evident even among those for whom the diversification activity is but one of a range of business interests. F9 could best be described as a portfolio entrepreneur, with farming just one element of a range of activities pursued. This farmer inherited half the family farm and attended agricultural college for a year, but he also established both a recycling and landscape gardening business. Cattlebreeding is the major part of the farm-based element of this farmer's enterprise portfolio, with meat sales accounting for a smaller proportion of the income. However, even for an entrepreneur with such diversified interests, what could be described as the emotional pull of this kind of economic activity is strong:

As an income source, it's probably less than $10 \%$ but a bit of my heart is in it, I would be sorry to give it up. (F9)

As noted above, the households in this study typically have a level of working experience outside agriculture and educational attainment both within and outside agriculture. In a large number of cases, this appears to have been a decisive factor in the 
entrepreneurial journey. A number of cases are particularly illuminating. Having left school at 15, F8 returned to school and college and completed a master's degree in marine science. His subsequent work in the fishing industry, which involved adding value to basic produce, inspired him to attempt the same on the family farm, which was at the time being run as a conventional beef operation by his brother.

A significant number of the participants in this study would describe themselves as being of a naturally entrepreneurial mindset and were motivated by the desire to run their own farm-based business. Allied with this is an openness to the entrepreneurial journey that springs from previous activity and experience. F2 described her experience:

I'm from an entrepreneurial background and have been self-employed most of my life. We had a bottled water operation on my own home farm....I studied nutrition and got to know about flax oil and the huge benefits of it. Though no one was growing it in Ireland, I thought there was definitely a market for it....I thought let's try and grow some....I wanted to produce something good, something native that would be suited to Irish people and that could replace imports.

For many, the choice of this kind of activity appears strongly linked to a desire to provide farmbased employment for more than just the farmer and to establish a sustainable family business that fits in with and is inextricably part of family life. As one farmer explained:

Before I started baking I was nursing but the hours were very erratic and uncertain; I wanted to spend more time at home around the family, for continuity and for work-life balance....Also the idea of being selfemployed appealed. My own family had a piggery and did their own label pork and bacon; it was what I grew up with so I suppose I wasn't too daunted. (F11)
It is apparent that experience gained outside the farm, as well as through the wider education described in the preceding section, resulted in a belief among respondents in their ability to respond to their particular mix of push and pull factors. Such self-efficacy is explored further in the following section.

\section{Sustaining the Journey: The Range of Skills Employed}

There was an overwhelming consensus among the participants in this study that a very wide and varied set of skills were usually needed when one is effectively operating at every stage of the food supply chain, from production through to sales and distribution. It is this requirement for a range of skills that at least partly explains the level of family involvement beyond the "producer" typically found in these enterprises. The following comment was typical of those that emerged:

There's just no way you could do it all yourself, there's just too much involved. One person wouldn't have the skills or even the time. (F5)

As noted previously, all but one of the participating households involve at least two members in short food supply chain activity. Where two people are employed full time, there appears to be quite a clear division of labor, where one person is largely concerned with the production side of the operation and the other with the operation beyond the farm gate. In the remaining enterprises, the level of involvement of other family members varies from skills-based support around particular aspects of the business to more general supplementary and occasional labor. A number of interviewees noted the value of having "another set of eyes," of having someone with whom to exchange ideas.

Notwithstanding the range of skills required, two categories emerged as most important in supporting the venture: (a) marketing and (b) risk management. Although a small number of participants referred to the importance of getting your product right and having an in-depth knowledge of it, it was apparent that the first stage of the supply chain (that is, production) is relatively 
unproblematic for most farm households. That is typically where their core skills, experience-and sometimes interest-lie. Marketing lies outside the set of skills required on the typical conventional farm, and it is therefore unsurprising that the focus of most participants' conversations on skills was on those needed to engage with consumers and intermediaries directly and to actually go on to sell what you produce at the correct price. One farmer noted:

You don't get paid for making it but for selling it. That's the most important thing to remember. Being able to get out there and sell, coming from a farming background, that's where most people fall down. You have to realize how much other food businesses spend on marketing....You have to make a huge time commitment to the sales end of it. (F5)

A number of participants noted that you are "selling yourself" and your "story" as much as your product. In line with this, most participants mentioned the necessity of having very good social skills and of enjoying, or at least not minding, meeting and interacting with people all the time. The following comments were typical:

You have to be a people person, if you can't deal with the good, bad and indifferent customer, you'll fail. It's work every day, you have to capture and deal with and retain every customer. Return customers are the thing and you can't have a set sales patter, you have to adapt constantly.... You have to sell your whole self. (F7)

If you don't have the people skills to sell it, you'd have to have a really, really unique product or be doing it so much better than anyone else. (F4)

Similarly, some interviewees noted the importance of media exposure in promoting their businesses, but again reflected that the ability to pursue the media exposure, and to go on to sell themselves and tell their stories are skills in themselves.
Management of the level of exposure to various sources of risk emerged as a key business competence. This was particularly evident in spreading risk across a number and range of market outlets. Five respondents sell into two different types of outlet, another five into three different types and the remaining five into four or more types. Many of the participants in this research spoke of the need to spread risk and not rely overly on either one type of outlet or indeed one individual market or restaurant or shop, however successful. As one noted:

I've come to the conclusion that the notion of big scale, of making the big deal, is a nonrunner....You have to spread your risk. (F15)

This aligns with their motivation to gain and maintain a level of independence in the marketplace and to guard against dependence on powerful buyers. The emphasis on maintaining this level of control reaches into the very meaning of what short food supply chains are and highlights the difference between this business model and the more mainstream and dominant business logic:

People have this idea that to get bigger is better but it isn't always. For example, just because you get listed with a particular retail chain, or get into a particular restaurant doesn't mean you should go on to supply them. (F11)

High levels of the kind of "entrepreneurial astuteness" described in the literature review were also evident among most of the farmers in this study:

You have to be constantly entrepreneurial and adaptable, always looking for opportunities, thinking of ways of maximizing value.... They all add up. (F1)

You have to be continually working on your business rather than always working in your business. (F8)

A further aspect of "astuteness" identified 
among the farmers in this study is the capacity to not only seek out and avail themselves of opportunities and supports, ${ }^{4}$ but also an alertness to levels of investment appropriate to their business model. The majority of participants in this research have availed themselves of hard and/or soft supports through the LEADER ${ }^{5}$ program or from support agencies. However, a significant number of participants noted the importance of exercising good judgement when it comes to taking advantage of any opportunity:

You need to get out and get lots of relevant information and advice. However, you need to be careful who you get it from; people from a large business background might encourage you to spend money you don't need to spend. (F15)

Given the vagaries of the food business, it is also apparent that those seeking to add value and sell more directly need a level of toughness and determination. As one farmer put it:

You need resilience and to just keep going. Setting up the business is like doing an intense 3 to 4 year degree and it's a very steep learning curve. There were probably plenty of times we should have quit. (F8)

While self-efficacy at the farm-household level emerged as a key factor prompting the decision to diversify, the skills and business acumen acquired along the way since this decision are inevitably important. Furthermore, the activity pursued appears very much based on a belief in this business model, and this in itself emerges as a defining characteristic of these farm households. The interviews with farmers in this study suggest that a level of selfbelief, perhaps even "cussedness," is indeed needed to operate outside the mainstream farming culture:

\footnotetext{
${ }^{4}$ The majority of participants in this research have taken advantage of hard supports such as grants and/or soft supports such as training, technical assistance, marketing support, etc. from rural development support agencies. ${ }^{5}$ The LEADER Initiative (Liaisons entre actions de
}

I get all sorts of reactions from "best of luck" to "you're mad" to "they won't pay you" to the more traditional farmers who'd want nothing to do with it. (F9)

There was a bit of begrudgery ${ }^{6}$ initially, but you can wear that opinion down, especially by employing people. The cultural barrier is there but you ignore it. We were the talk of the meat guys for a while with a fair bit of "who do they think they are," but now people are coming to us looking to sell. (F8)

Some of the participants in this study drew deliberate attention to what they saw as the differences between themselves and other, conventional farmers:

A lot comes down to pride; some people just would not stand on a street selling things. They'd be afraid people would say "that fella must be short of money." (F15)

[There is] a lost set of skills which came along with more mixed enterprises, such as saving grain, or being self-sufficient as a family. It's hard to describe some modern day farmers as such, it's very much a monoculture.....with overspecialization and overproduction, some are more tractor drivers than farmers. (F14)

\section{Discussion}

This study confirms the complex nature of the motivations of farm families embarking on diversification activities that are highlighted in a range of other studies (Couzy \& Dockes, 2008; Hansson et al., 2013; Northcote \& Alonso, 2011; Vik \& McElwee, 2011). Although economic motivations, and particularly the desire to realize greater economic value from products perceived to be of high quality, are to the forefront, they are

developpement de l'économie rurale) is a European Union initiative to support rural development projects initiated at the local level in order to revitalize rural areas and create jobs. ${ }^{6}$ This is a term commonly used in Ireland to describe resentment of a person who has achieved success or wealth. 
typically accompanied by a range of other personal, social, and ideological motivations. It is no simple task to disentangle these motivations and place them into the "push" or "pull" framework described earlier, not least because as Vik and McElwee (2011) have put it, both push and pull may be economic and social. Although the balance may vary, both push and pull factors are clearly present in most cases. For example, beef producers may be pushed by low commodity prices to explore adding value and selling directly, but they are surely also being pulled by their own particular desires to establish an enterprise or to do something different, a pull clearly not felt by most fellow beef farmers. The entrepreneurial journey of the participants in this study seems to have been largely, though not solely, triggered by internal characteristics and personality factors (i.e., largely pull factors, or Hennon's [2012] notion of intent) than by events or overwhelming push factors. Many of the personality factors associated with entrepreneurial activity identified in the literature (Covin \& Wales, 2011; Lumpkin \& Dess, 1996; McElwee, 2008), such as optimism, propensity for risk-taking, self-belief, and autonomy were found, though to varying degrees, among the participants in this study.

One of the most notable findings from this study is that an ideological commitment to exploring alternatives to the conventional food system underpins much of the decision-making of the farm households. For a substantial number of households in this study, the method of selling is inextricably linked with, and to some extent, determined by, the distinct nature of the products they have to offer and their overall outlook on the food system. Many clearly see themselves as a bulwark against processes of homogenization, centralization, and specialization in the conventional food system, or as championing alternative (or as they would perceive it, saner) approaches to both producing and distributing food. They could legitimately be described as "socially responsible entrepreneurs," portrayed in Lauwere, Verhaar, and Drost's (2002) classification of farmers as those who have a high score on social orientation and show interest for new company branches, nature and landscape management, or organic agriculture or horticulture, without really striving to be a large company. While all farmers may be seen as having some type of socially entrepreneurial role (McElwee, 2008), this role is more overt and deliberate in the case of these types of farm households. Most see themselves as being the kind of change makers or social innovators described in the literature on social entrepreneurship (Dees, 1998; Dees \& Anderson, 2006). In their quest to live according to their own "life plans," these entrepreneurs not only seek to realize economic goals, but also have a clear sense of the "place" that the farm household takes up in a broader social structure. The diversification activity has clearly become an essential part of the farmer household's (and by extension the entrepreneurs') identity. Farm household autonomy is fundamental to this positioning; indeed, subordination to what is perceived as powerful socio-economic and political hegemony sometimes prompted the entrepreneurial intent. It is also interesting to find that both previous experience and expertise across the family unit supported strong self-efficacy at the outset. Thus both opportunity and wherewithal to take action were evident.

Although no comparative study has been done with conventional farm households in Ireland, it appears from this study that at least one member of the farm households embarking on this kind of activity will usually have at least one of the following: significant off-farm work and life experience; an entrepreneurial background; and/or education qualifications outside agriculture and farming. This aligns with similar studies in other jurisdictions (McElwee \& Bosworth, 2010; Meert et al., 2005). Further, unless it is to remain at a relatively simple level, with limited potential for growth, this kind of activity appears to require the inputs (that is, the skills and the labor) of more than one member of the farm household. This input ranges from minimal, often specific skills-based inputs to whole family involvement, and it appears to be critical. These findings are wholly in line with other studies of farm diversification that have highlighted the importance of family involvement in diversification activities (Alsos et al., 2003; Hansson et al., 2003). The comparatively high level of female involvement in the farm-based enterprises included in this 
study is similar to that found in studies in other jurisdictions, which place the female partner at the center of this type of diversification as instigator, manager, or, at the very least, supporter of the male partner (Anthopoulou, 2010; Bock, 2004).

There is strong evidence from this study of the presence of higher-level, more entrepreneurial skills of the type described by Hennon (2012), which he associates with more entrepreneurial farmers. There was consensus that a very broad range of skills are needed for this particular type of diversification, which requires entrepreneurs to effectively operate at every stage of the food supply chain. However, within the context of this study, these skills were not necessarily, and indeed were only perhaps rarely, found in one person. As noted previously, the presence of a collective experience and skill set appears crucial to the success and sustainability of these farm household enterprises. Although many of the participants in this research are operating at a relatively small scale, there is also evidence of the entrepreneurial astuteness described by Hennon (2012). The typical farm household that embarks on this journey assembles and juggles a large range of outlets for their products, with a majority selling into three or more. Each type of outlet has its benefits and its drawbacks, and every farm household embarking on short food supply chain activity assembles a mix of outlets which works for them and their operation.

In examining the web of economic, social, and personal factors in the entrepreneurial journey, this study adds to the growing literature on farm entrepreneurship and, more specifically, to the more limited literature on farm family entrepreneurship. It also confirms that farm entrepreneurship is a special case in the entrepreneurship literature, demanding further investigation and the development of models that can capture the complexity of the entrepreneurial journey.

\section{Conclusions}

The starting point for this study was the lack of diversification activity among Irish farmers, particularly with regard to added-value food production. When viewed alongside the very low proportion of Irish farm households who have chosen to explore this type of diversification, the participants in this study could quite legitimately be described (and appear to see themselves) as pioneers or outliers. Of particular note is the relative importance of motivations that are not strictly economic and are in some cases firmly ideological, such as the ongoing desire to challenge and provide an alternative to the conventional food system, or the commitment to sustaining the family farm and rural way of life. The particular zealof the farm households in this study may arise in part from the very real barriers to the development of this segment of the Irish food industry, such as the dominance of commodity agriculture, limited food culture, and market size (Macken-Walsh, 2009; Tovey, 2009). Within this particular economic, social, and cultural milieu, diversification at even a small scale (such as was found in this study) can be described as an inherently entrepreneurial action. Indeed, a small-scale business model or logic is a fundamental characteristic of the farm households studied, and this research highlights the inherent value and sustainability of these enterprises. This contrasts with the dominant productivist logic or mindset in the wider agricultural and policy communities, which places value on scale and growth. This is a mindset rooted within a commodity production culture that prevails within mainstream agriculture. However, a more pluriactive approach to rural development values the contribution that these microscale enterprises make to the socioeconomic fabric of rural areas and their linkage, both economic and ideological, with urban areas. Hence this could inform agricultural extension workers, rural development practitioners, and policy-makers both in Ireland and in other countries or regions with similarly low levels of farm diversification.

The cornerstone of any attempts to encourage more farmers to at least explore this kind of diversification activity appears to be the building of a culture of entrepreneurialism among farm households and not just farmers. This could involve precommercial animation work, further mainstreaming of diversification into farmer education programs, peer-to-peer mentoring, funding of training, appropriate grant support, and other activities. Any animation or development work carried out in this sector also clearly needs to 
encompass the skills, experience, interests, and ambitions of the farm household as a whole. It is also necessary to continue to look beyond the current farmer base-and possibly entrenched notions of what a farmer is-to work with new entrants to the food sector, including those operating intensively from very small holdings such as we encountered in this research. This study specifically highlights the inherent value of the more small-scale farmer entrepreneurs who may never scale up or require intensive capital support, but who contribute to overall rural sustainability and economic life and who are meeting their own multiple goals. Above all, the dynamic, complex, and heterogeneous nature of farm entrepreneurialism in this setting suggests that farmer advice and support must of necessity be tailored to individual farm circumstances. New mechanisms may have to be developed to enable support bodies to measure, valorize, and validate this sometimes less obvious area of their work. This is also in line with Barbieri and Mahoney's (2009) assertion that performance assessment of diversification must incorporate valid measures of the accomplishment of a range of different goals that encourage farmers to diversify.

The phenomenological approach adopted in this study encouraged respondents to return to their decision to embark on a particular journey (i.e., diversification into short food supply chains) and to explore the meanings that they attached to this decision. We also explored what Jayawarna et al. (2007) would describe as the unfolding nature of entrepreneurial life in seeking to understand the subsequent lived experience of these farm households. The findings point to persistent motivation that sustains the activity associated with short food supply chains (i.e., this trajectory) and as such, these farm households display an embedded rather than whimsical behavior. This approach could usefully be applied to a further comparative study of Irish farm households who have diversified into other types of activities (e.g., tourism, forestry, energy), not least to explore the extent to which the kind of ideological motivations found in this study are also present. Similarly it would be of interest to explore the nature of the web of economic, social, and personal factors in the entrepreneurial journey of other types of family businesses, particularly those embedded in rural communities, where they may fulfill a similarly "social entrepreneurial" role.

\section{References}

Alsos, G. A., Ljunggren, E., \& Pettersen, L. T. (2003). Farm-based entrepreneurs: What triggers the startup of new business activities? Journal of Small Business and Enterprise Development, 10(4), 435-443. http://dx.doi.org/10.1108/14626000310504747

Anthopoulou, T. (2010). Rural women in local agrofood production: Between entrepreneurial initiates and family strategies. A case study in Greece. Journal of Rural Studies, 26(4), 394-403. http://dx.doi.org/10.1016/j.jrurstud.2010.03.004

Barbieri, C., \& Mahoney, E. (2009). Why is diversification an attractive farm adjustment strategy? Insights from Texas farmers and ranchers. Journal of Rural Studies, 25(1), 58-66. http://dx.doi.org/10.1016/j.jrurstud.2008.06.001

Bock, B. B. (2004). Fitting in and multi-tasking: Dutch farm women's strategies in rural entrepreneurship. Sociologia Ruralis. 44(3), 245-260. http://dx.doi.org/ 10.1111/j.1467-9523.2004.00274.x

Bord Bia. (2007). Guide to selling through farmers' markets, farm shops and box schemes in Ireland. Dublin: An Bord Bia. http://www.bordbia.ie/industry/farmers/ Pages/default.aspx

Brown, G. (2010). Rural development and the LEADER approach in the UK and Ireland. Fife, UK: Carnegie Trust UK. http://www.carnegieuktrust.org.uk/ publications/rural-development-and-the-leaderapproach-research/

Clark, J. (2009). Entrepreneurship and diversification on English farms: Identifying business enterprise characteristics and change processes. Entrepreneurship \& Regional Development, 21(2), 213-236. http://dx.doi.org/10.1080/08985620802261559

Cooke, P. (1998). Introduction: Regional innovation systems-An evolutionary approach. In H.-J. Braczyk, P. Cooke, \& M. Heidenreich (Eds.), Regional Innovation Systems: The Role of Governances in a Globalized World (2nd ed.) (pp. 2-25). London: UCL Press. 
Couzy, C., \& Dockes, A.-C. (2008). Are farmers businesspeople? Highlighting transformations in the profession of farmers in France. International Journal of Entrepreneurship and Small Business, 6(3), 407-420. http://dx.doi.org/10.1504/IJESB.2008.019135

Covin, J. G., \& Wales, W. J. (2011). The measurement of entrepreneurial orientation. Entrepreneurship Theory and Practice, 36, 677-702. http://dx.doi.org/ 10.1111/j.1540-6520.2010.00432.x

Crowley, C., \& Meredith, D. (2015). Agricultural restructuring in the EU: An Irish case study. In A. K. Copus \& P. de Lima (Eds.), Territorial Cohesion in Rural Europe: The Relational Turn in Rural Development (pp. 173-189). London: Routledge.

Dabson, B. (2008, May). Entrepreneurs, entrepreneurship and regional development. Presented at the Australian Regional Economies Conference, Terrigal, NSW, Australia. Retrieved from http://www.rupri.org/ Forms/Dabson Australia May08.pdf

Dees, J. G. (1998/2001). The meaning of "social entrepreneurship.” Retrieved from https://entrepreneurship.duke.edu/news-item/ the-meaning-of-social-entrepreneurship/

Dees, J. G., \& Anderson, B. B. (2006). Framing a theory of social entrepreneurship: Building on two schools of practice and thought. In R. Mosher-Williams, (Ed.), Research on Social Entrepreneurship: Understanding and Contributing to an Emerging Field (Occasional Paper Series Vol. 1, No. 3, pp. 39-66). Indianapolis, Indiana: Association for Research on Nonprofit Organizations and Voluntary Action (ARNOVA). Retrieved from http://www.arnova.org/?page=publications

Degeorge, J.-M., \& Fayolle, A. (2011). The entrepreneurial process trigger: A modelling attempt in the French context. Journal of Small Business and Enterprise Development, 18(2) 251-277. http://dx.doi.org/10.1108/14626001111127061

Department of Agriculture, Food and the Marine. (2015). Fact sheet on Irish agriculture - November 2015. Retrieved from http://www.agriculture.gov.ie/publications/2015/

Feagan, R., Morris, D., \& Krug, K. (2004). Niagara Region farmers' markets: Local food systems and sustainability considerations. Local Environment, 9(3), 235-254.

http://dx.doi.org/10.1080/1354983042000219351
Feenstra, G. W., Lewis, C. C., Hinrichs, C. C., Gillespie, G. W., Jr., \& Hilchey, D. (2003). Entrepreneurial outcome and enterprise size in US retail farmers' markets. American Journal of Alternative Agriculture, 18(1), 46-55.

http://journals.cambridge.org/action/displayIssue? iid=AJA\&volumeId=18\&seriesId=0\&issueId $=01$

Fonte, M. (2008). Knowledge, food and place. A way of producing, a way of knowing. Sociologia Ruralis, 48(3), 200-222. http://dx.doi.org/10.1111/j.14679523.2008.00462.x

Gasson, R., Crow, G., Errington, A., Hutson, J., Marsden, T., \& Winter, D. M. (1988). The farm as a family business: A review. Journal of Agricultural Economics, 39(1), 1-41. http://dx.doi.org/10.1111/ j.1477-9552.1988.tb00560.x

Gasson, R., \& Errington, A. (1993). The Farm Family Business. (1 ${ }^{\text {st }}$ ed.), Oxon, UK: CAB International.

Grande, J. (2011). New venture creation in the farm sector-Critical resources and capabilities. Journal of Rural Studies, 27(2), 220-233. http://dx.doi.org/10.1016/j.jrurstud.2011.02.003

Grant Thornton. (2012). Food: The secret ingredient to Irish tourism and export growth (Grant Thornton Business Insight Survey 2012). Retrieved from http://grantthornton.pl/sites/default/files/raporty LGrant-Thornton-Business-Insight-Survey2012_Ireland_jest.pdf

Guthrie, J., Guthrie, A., Lawson, R., \& Cameron, A. (2006). Farmers' markets: The small business counter-revolution in food production and retailing. British Food Journal, 108(7), 560-573. http://dx.doi.org/10.1108/00070700610676370

Hansson, H., Ferguson, R., Olofsson, C. \& RantamäkiLahtinen, L. (2013). Farmers' motives for diversifying their farm business - The influence of family. Journal of Rural Studies, 32, 240-250. http://dx.doi.org/10.1016/j.jrurstud.2013.07.002

Haugen, M. S., \& Vik, J. (2008). Farmers as entrepreneurs: The case of farm-based tourism. International Journal of Entrepreneurship and Small Business, 6(3), 321-336. http://dx.doi.org/10.1504/IJESB.2008.019130

Heanue, K., \& Macken-Walsh, Á. (2010). The Rural Development Programme (2007-2013) and farmer innovation: A review to date and look to the future (Working Paper Series No. 10-WP-RE-07). Athenry, Galway: Teagasc Rural Economy 
Research Centre. Retrieved from http://t-stor. teagasc.ie/bitstream/11019/699/1/farmer\%20inno vation.pdf

Hennon, C. B. (2012). Entrepreneurship, farming, and identity: A phenomenological inquiry. In T. BurgerHelmchen (Ed.), Entrepreneurship - Gender, Geographies and Social Context (pp. 249-294). Rijeka, Croatia: Intech.

Hildenbrand, B., \& Hennon, C. B. (2008). Beyond the concept of "getting big or getting out":

Entrepreneurship strategies to survive as a family farm. International Journal of Entrepreneurship and Small Business, 6(3), 479-495. http://dx.doi.org/10.1504/IJESB.2008.019140

Hinrichs, C. C., Gillespie, G. W., \& Feenstra, G. W. (2004). Social learning and innovation at retail farmers' markets. Rural Sociology, 69(1), 31-58. http://onlinelibrary.wiley.com/doi/10.1526/ $\underline{003601104322919892 / \text { abstract }}$

Hofmann, J. V. (2009). Family mindset as predictor of entrepreneurship in German family firms (Unpublished doctoral dissertation). University of St. Gallen, Bamberg, Germany.

Hutchison, E. D. (2011). Dimensions of human behavior: The changing life course ( $4^{\text {th }}$ ed.). Los Angeles: SAGE.

Ilbery, B. (1992). State assisted farm diversification in the United Kingdom. In I. R. Bowler, C. R. Bryant, \& M. D. Nellis (Eds.), Contemporary Rural Systems in Transition (Vol. 1, Agriculture and Environment; pp. 100-116). Wallingford: CABI.

Ilbery, B., \& Bowler, I. (1998). From agricultural productivism to post-productivism. In B. Ilbery (Ed.), The Geography of Rural Change (pp. 57-84). Harlow, UK: Longman.

Jayawarna, D., Rouse, J., \& Kitching, J. (2013). Entrepreneur motivations and life course. International Small Business Journal, 31(1) 34-56. http://dx.doi.org/10.1177/0266242611401444 Jayawarna, D., Rouse, J., \& Macpherson, A. (2007, November). Pathways to entrepreneurship across the lifecourse: An innovative model utilizing longitudinal data from the British Household Panel Survey. Presented at the Institute of Small Business and Entrepreneurship Conference (ISBE), Glasgow.

Lauwere, C., de, Verhaar, K. \& Drost, H. (2002). Het mysterie van het ondernemerschap: Boeren en tuinders op zoek naar nieunve wegen in een dynamische maatschappij
[The mystery of entrepreneurship: Farmers looking for new pathways in a dynamic society] (Dutch with English summary). Wageningen, the Netherlands:

Wageningen University and Research Centre. Retrieved from http://library.wur.nl/WebQuery/ wurpubs/322356

Lumpkin, G. T., \& Dess, G. G. (1996). Clarifying the entrepreneurial orientation construct and linking it to performance. The Academy of Management Review, 21(1), 135-172. http://instruct.uwo.ca/business/ bus020-mwf/PHD-4.pdf

Macken-Walsh, Á. (2009). Barriers to change: A sociological study of rural development in Ireland (Teagasc National Report No 53). Athenry, Galway: Teagasc Rural Economy Research Centre.

Macken-Walsh, Á., Byrne, A., Curran, T., \& Roche, B. (2014). Strategies of resilience: Cooperation in Irish family farming. TResearch, 9(2), 28-29. https://www.teagasc.ie/media/website/ publications/2014/TResearch Summer2014.pdf

McElwee, G. (2008). A taxonomy of entrepreneurial farmers. International Journal of Entrepreneurship and Small Business, 6(3), 465-478. http://dx.doi.org/10.1504/IJESB.2008.019139

McElwee, G., \& Bosworth G. (2010). Exploring the strategic skills of farmers across a typology of farm diversification approaches. Journal of Farm Management, 13(12), 819-838. http://www.ingenta connect.com/contentone/iagrm/jfm/2010/000000 13/00000012/art00003

McElwee, G., \& Robson, A. (2004). Diversifying the farm: Opportunities and barriers. Finnish Journal of Rural Research and Policy, 2004(4), 84-96. http://www.mua.fi/inenglish/journal/

McNally, S. (2001). Farm diversification in England and Wales: What can we learn from the Farm Business Survey? Journal of Rural Studies, 17(2), 247-257. http://dx.doi.org/10.1016/S0743-0167(00)00050-4

Meert, H., Van Huylenbroeck, G., Vernimmen, T., Bourgeois, M., \& van Hecke, E. (2005). Farm household survival strategies and diversification on marginal farms. Journal of Rural Studies, 21(1), 81-97. http://dx.doi.org/10.1016/j.jrurstud.2004.08.007

Meredith, D. (2011). Farm diversification in ireland. TResearch, 6(1), 34-35. https://www.teagasc.ie/media/website/publication s/2011/71/71 TResearch 201103.pdf 
Meredith, D., Heanue, K., \& McCarthy, S. (2012, October). Farm development: Attitudes of farmers to farm diversification. Paper presented at the National Rural Development Conference, Enfield, County Meath, Ireland.

Moore, O. (2003). Organic organisations and movement bifurcations: Collective identity or otherwise in the organic movement in Ireland, 1936-1991. Paper presented at the XX Congress of the European Society for Rural Sociology (ESRS), Sligo, Ireland.

Northcote, J., \& Alonso, A. D. (2011). Factors underlying farm diversification: The case of Western Australia's olive farmers. Agriculture and Human Values, 28(2), 237-246. http://dx.doi.org/10.1007/s10460-010-9274-x

Phelan, C., \& Sharpley, R. (2011). Exploring agritourism entrepreneurship in the UK. Tourism Planning and Development, 8(2), 121-136. http://dx.doi.org/10.1080/21568316.2011.573912

Renting, H., Marsden, T., \& Banks, J. (2003). Understanding alternative food networks: Exploring the role of short food supply chains in rural development. Environment and Planning $A$, 35(3), 393-411. http://dx.doi.org/10.1068/a3510

Seuneke, P., Lans, T., \& Wiskerke, J. S. C. (2013). Moving beyond entrepreneurial skills: Key factors driving entrepreneurial learning in multifunctional agriculture. Journal of Rural Studies, 32, 208-219. http://dx.doi.org/10.1016/j.jrurstud.2013.06.001

Slee, B., \& Kirwan, J. (2007, March). Exploring bybridity in food supply chains. Paper presented at the 105th European Association of Agricultural Economists (EAAE) Seminar, Bologna. http://purl.umn.edu/7885

Smith, R., \& McElwee, G. (2013). Confronting social constructions of rural criminality: A case story on 'illegal pluriactivity' in the farming community.
Sociologia Ruralis, 53(1), 112-134. http://dx.doi.org/ 10.1111/j.1467-9523.2012.00580.x

Smithers, J., Lamarche, J., \& Joseph, A. E. (2008). Unpacking the terms of engagement with local food at the farmers' market: Insights from Ontario. Journal of Rural Studies, 24(3), 337-350. http://dx.doi.org/10.1016/j.jrurstud.2007.12.009

Teagasc. (2012). National Farm Survey 2011. Dublin: Teagasc. Retrieved from https://www.teagasc.ie/ publications/2012/national-farm-survey-2011.php

Tovey, H. (2006). New movements in old places? The alternative food movement in rural Ireland. In L. Connolly \& N. Hourigan (Eds.), Social Movements and Ireland (pp. 168-189). Manchester, UK: Manchester University Press.

Tovey, H. (2009). 'Local food' as a contested concept: Networks, knowledges and power in food-based strategies for rural development. International Journal of Sociology of Agriculture and Food, 16(2), 21-35. http://www.ijsaf.org/contents/16-2/tovey/ index.html

Vik, J., \& McElwee, G. (2011). Diversification and the entrepreneurial motivations of farmers in Norway. Journal of Small Business Management, 49(3), 390-410. http://dx.doi.org/10.1111/j.1540-627X.2011. 00327.x

Whatmore, S. (1991). Farming Women: Gender, Work and Family Enterprise. London: Macmillan.

Woods, M. (2005). Rural Geography; Processes, Responses and Experiences in Rural Restructuring. London: SAGE.

Wright, M., \& Kellermanns, F. W. (2011). Family firms: A research agenda and publication guide. Journal of Family Business Strategy, 2(4), 187-198. http://dx.doi.org/10.1016/j.jfbs.2011.10.002

Yin, R. K. (2003). Case Study Research, Design and Methods (3rd ed.). Thousand Oaks, California: SAGE. 